\title{
Effects of long-term physical exercise in the skeletal muscles of rats
}

\author{
ADALA, J. F. ${ }^{*}$ and CAMPOS, G. E. R. \\ Departamento de Biologia Estrutural e Funcional, Instituto de Biologia, Universidade Estadual de Campinas - \\ UNICAMP, Av. Bertrand Russel, s/n, Cidade Universitária Zeferino Vaz, CEP 13083-865, Campinas, SP, Brazil \\ *E-mail: jubruadala@yahoo.com.br
}

\begin{abstract}
Introdcution: The effects of long-term physical exercise in the skeletal muscles were evaluated. Methods: 30 male Wistar rats, 25 days old each, were divided in 2 groups: trained (TG, $\mathrm{n}=21$ ) and sedentary $(S G, \mathrm{n}=9$ ). The TG group was subdivided in 3 groups: TGI, TGII and TGIII, $n=7$ in each group, and the SG was also subdivided in 3 groups: SGI, SGII and SGIII, $\mathrm{n}=3$. The animals of the TG (I, II and III) performed running exercise on a electric running machine for 3, 6 and 9 weeks respectively. The animals of the sedentary groups remained without any exercise. After the experimental period the soleus (SOL), the extensor digitorum longus (EDL) and the plantaris (PL) muscles were extracted, weighed and analyzed by the histochemichal technique of mATPase to observe possible changes. Results: The TGIII showed a significant increase in the absolute values of muscle weight when compared to the TGI and TGII. There was an increase in the distribution of type I fibers and a decrease in types IIC and IIA in the SOL muscle. The EDL muscle showed an increase in IIA fibers and a decrease in IID IIB types. As for the PL muscle there was an increase in types IIA and IIAD and a decrease in IID type fibers. Conclusion: Physical exercise causes changes in the distribution of fiber types in the skeletal muscles of rats and confirms the capacity of the fibers to adapt to the requirements of the proposed physical exercise in order to achieve a better performance.
\end{abstract}

Keywords: fiber types, physical exercise, muscle plasticity.

\section{Introduction}

Skeletal muscles are constituted in general of several types of fibers which have different metabolic and contractile properties. Myosin constitutes one of the main muscular proteins and it is related to the contraction speed of the muscular fiber. The expression of one or more myosin isoforms determines the various types of fibers. The slow isoform is denominated Myosin Heavy Chain I (MHCI) and the fast ones are denominated: MHCIIa, MHCIId and $\mathrm{MHCIIb}$. There are still the hybrid fibers which express two or more myosin isoforms: IC, IIC, IIAC, IIAD, IIDA, IIDB and IIBD. This diversity of fibers allows the muscle to continuously adjust itself to functional needs, granting considerable plasticity to it. Several factors such as physical exercise, electrical stimulation, denervation, reinnervation, aging, hormones constitute stimuli that can influence the phenotype of mammals' skeletal muscles (PETTE and STARON, 2001).

The transition of fibers demonstrated by long-term and force exercises are concentrated just in the alteration of fast fibers, that is, a change of fibers from type IIB to type IIA. The high intensity of training can, although, cause a transition beyond the population of fast fibers (KADI, ERIKSSON, HOLMNER et al., 1999; DEMIREL, POWERS, NAITO et al., 1999). Importantly, the structural and metabolic properties of each fiber type can be remodeled in response to hormonal and metabolic changes and by muscle activity (MURGIA, NAGARAJ, DESHMUKH et al., 2015).

It is well established that long-term exercise promotes various adaptations in the skeletal muscle, including an increase of the oxidative and antioxidative capacity of fibers, as stated by Powers, CRISWELL, LAWLER et al. (1994). However, many questions still persist regarding the effect of long-term training in myosin isoforms. Despite the evidences that long-term exercises promote changes in the phenotype of skeletal muscles according to Sullivan, POWERS, CRISWELL et al. (1995), the diversity of fibers in one muscle grants it the property of changing its characteristics before a specific stimulus, promoting adaptations in its energetic and myofibrillar system. Fibers adapt according to the requirement of the activities in order to achieve a better performance in its execution. Therefore, it was of interest to analyze the soleus (SOL), the extensor digitorum longus (EDL) and the plantaris (PL) muscles of rats during a 9 week training period. The SOL is a slow contraction muscle, with almost every fiber being of type II. The EDL and PL are fast contraction muscles, with almost all of their fibers being type II. Therefore, the goal of this study was to analyze the possible changes in the weight and phenotype of the SOL, EDL and PL muscles during 9 week of training.

\section{Materials and Methods}

\subsection{Animals}

30 Wistar rats which were 25 days old coming from Unicamp (State University of Campinas) Bioterism Center were used. The animals were divided in 2 groups: trained ( TG, $\mathrm{n}=21$ ) and sedentary ( $\mathrm{SG}, \mathrm{n}=9$ ). The sedentary group was subdivided in 3 groups with 3 animals each: SGI, SGII and SGIII. The animals were kept in a controlled environment with a constant temperature of $22^{\circ} \mathrm{C}$ and were fed with a standard diet of water and rat food at pleasure. 


\subsection{Selection of the animals for the training}

As soon as the animals arrived at the research place, a 5 day selection protocol was realized to identify which ones would form the trained and the sedentary groups. The 30 animals, which were 25 days old, were separated into 3 groups: GI, GII and GIII. In the first selection day all the groups were kept in their respective cages and put next to a functioning running machine during 20 minutes, in order to adapt the animals to the sound of the equipment. This procedure was repeated in the second day and after it the 10 animals of each group were put on the running machines, now turned off, for 10 minutes. In the third day the procedure of the previous day was repeated. In the fourth day, along with the previous procedures, the animals of each group were distributed in the lanes of a functioning running machine, kept at a minimum speed for 3 to 5 minutes. The most active animals started to be identified. In the fifth day the same procedure of the previous day was realized, and the animals with the highest physical disposition were separated to form the trained groups.

\subsection{Training}

The animals were trained in the Anatomy Department of Unicamp in an electrical running machine with lanes for 7 animals, a device developed by the department itself. The animals of each trained group were numbered and always trained in the same lanes. The animals of the GTI, GTII and GTIII groups had a one week adaptation period to the running machine. This period was considered the first week of training where the animals ran at a minimum speed of $10 \mathrm{~m} / \mathrm{min}$ with an increasing time of 5 to 20 minutes. After the adaptation period the animals started the physical exercise period in a sub maximum speed, without inclination or increasing time. The training sessions were realized 5 days a week during 3, 6 and 9 weeks for the GI, GII and GIII groups respectively. In the second week the animals ran 25 minutes at $11 \mathrm{~m} / \mathrm{min}$; in the third week, 30 minutes at $12 \mathrm{~m} / \mathrm{min}$; in the fourth week, 35 minutes at $12 \mathrm{~m} / \mathrm{min}$; in the fifth week, 40 minutes at $13 \mathrm{~m} / \mathrm{min}$; in the sixth week, 45 minutes at $14 \mathrm{~m} / \mathrm{min}$; in the seventh week, 50 minutes at $15 \mathrm{~m} / \mathrm{min}$; in the eighth week, 55 minutes at $16 \mathrm{~m} / \mathrm{min}$ and in the $9^{\text {th }}$ week, 60 minutes at $17 \mathrm{~m} / \mathrm{min}$. The animals needed no direct stimulus to finish each daily training session. The speed and time were always increased in the last day of each week and the animals always trained at the same period of the day, between 13 and 15 o'clock. The animals of the sedentary groups had no physical exercise at all.

\subsection{Preparation of the samples}

Immediately after the determined training periods $(3,6$ and 9 weeks) the animals were anesthetized and had their soleus (SOL), extensor digitorum longus (EDL) and plantaris (PL) muscles from the right rear leg extracted and weighed. The animals were then sacrificed with an overdose of the anesthesia. Afterwards, a sample of each muscle was extracted and frozen in isopentane chilled in liquid nitrogen at $-159^{\circ} \mathrm{C}$. The samples were stored in a freezer at $-80^{\circ} \mathrm{C}$ for further analyses.

The muscles were carried to a cryostat at $-24^{\circ} \mathrm{C}$ were they stayed for one hour before being cut. $12 \mu \mathrm{m}$ thick cuts were obtained. The cuts were placed on coverslips in such a way that each coverslip had at least two cuts of each muscle of the same animal. The coverslips remained stored in a freezer at $-80^{\circ} \mathrm{C}$ until every cut was obtained in order to submit all of them simultaneously to histochemical reactions.

\subsection{Histochemistry}

The main types and subtypes of muscular fibers (I, IC, IIC, IIA, IIAD, IID, IIDB and IIB) were delineated with the histochemical technique of mATPase (myofibrillar adenosine triphosphatase) (PETTE and STARON, 1993) after preincubation in $\mathrm{pH}$ levels of 4.3, 4,6 (BROOKE and KAISER, 1970) and 10.4 (GUTH and SAMAHA, 1970). Some adjusts were made in the aforementioned $\mathrm{pH}$ levels regarding the diversity among muscles of different species of animals. Photos of two fields of the cut in $\mathrm{pH} 4.6$ were taken thereafter; along with observation of the cuts in the 4.3 and $10.4 \mathrm{pH}$ levels, it was determined the number and the percentage of each type of fiber in the studied muscles.

\subsection{Statistics}

The data were submitted to the statistical test ANOVA, Comparison of Observed Percentages and Analysis of Variance, followed by the Tukey's HSD test of the groups. The significance level adopted was of $5 \%(\mathrm{p}<0.05)$.

\section{Results}

\subsection{Muscle weight}

The relative muscle weight of the animals from the TGI were compared with the respective SGI and it was observed that only the EDL muscle showed a significant decrease $(\mathrm{p}<0.05)$. The SOL muscle showed increase in the relative weight, although not significant $(\mathrm{p}<0.05)$, while the PL muscle showed a not significant $(\mathrm{p}>0.05)$ decrease in weight among the animals submitted to long-term training (Table 1 ).

Therefore, comparing the TGII and SGII groups, it was found a significant lower value $(\mathrm{p}<0.05)$ of the relative weight of the SOL, EDL and PL muscles. The comparison of the TGIII group with the respective SGIII showed a significant increase $(\mathrm{p}<0.05)$ in the relative weight of the EDL and PL muscles; the SOL muscle showed increase, although not significant $(\mathrm{p}>0.05)$.

\subsection{Types of muscular fibres}

The types of muscular (I,IC, IIC, IIA, IIAD, IID, IIDB and IIB) were delineated (Figure 1 ) and a percentage was obtained through the counting of fibers in the analyzed fields.

Therefore, comparing the distribution of fibers of the SOL muscle among the TGI and SGI there was a significant increase $(p<0.05)$ of I and IIC fibers $(93.62 \% ; 2.73 \%)$ and a significant decrease $(\mathrm{p}<0.05)$ of IIA type fibers $(3.18 \%)$ when compared to the sedentary group. Among the TGII and SGII set there was a significant increase $(\mathrm{p}<0.05)$ of type I fibers $(99.72 \%)$ and a significant decrease $(\mathrm{p}<0.05)$ of IIA and IIC fibers $(0.00 \%$ and $0.27 \%)$. GTIII group showed significant increase $(\mathrm{p}<0.05)$ of type I fibers $(97.63 \%)$ and significant decrease $(\mathrm{p}<0.05)$ of IIA and IIC fibers $(1.36 \%$ and $0.99 \%)$ respectively when compared to SGIII group. As for the distribution of IC fibers in the SOL muscle among the groups, it was not significant $(\mathrm{p}>0.05)$ (Table 2).

As for the distribution of the SOL muscle among the trained groups TGI, TGII and TGIII it was observed that type I fibers showed a significant increase $(\mathrm{p}<0.05)$ after 5 and 6 weeks of training (93.62\% and $99.72 \%)$ and after 9 weeks a significant 


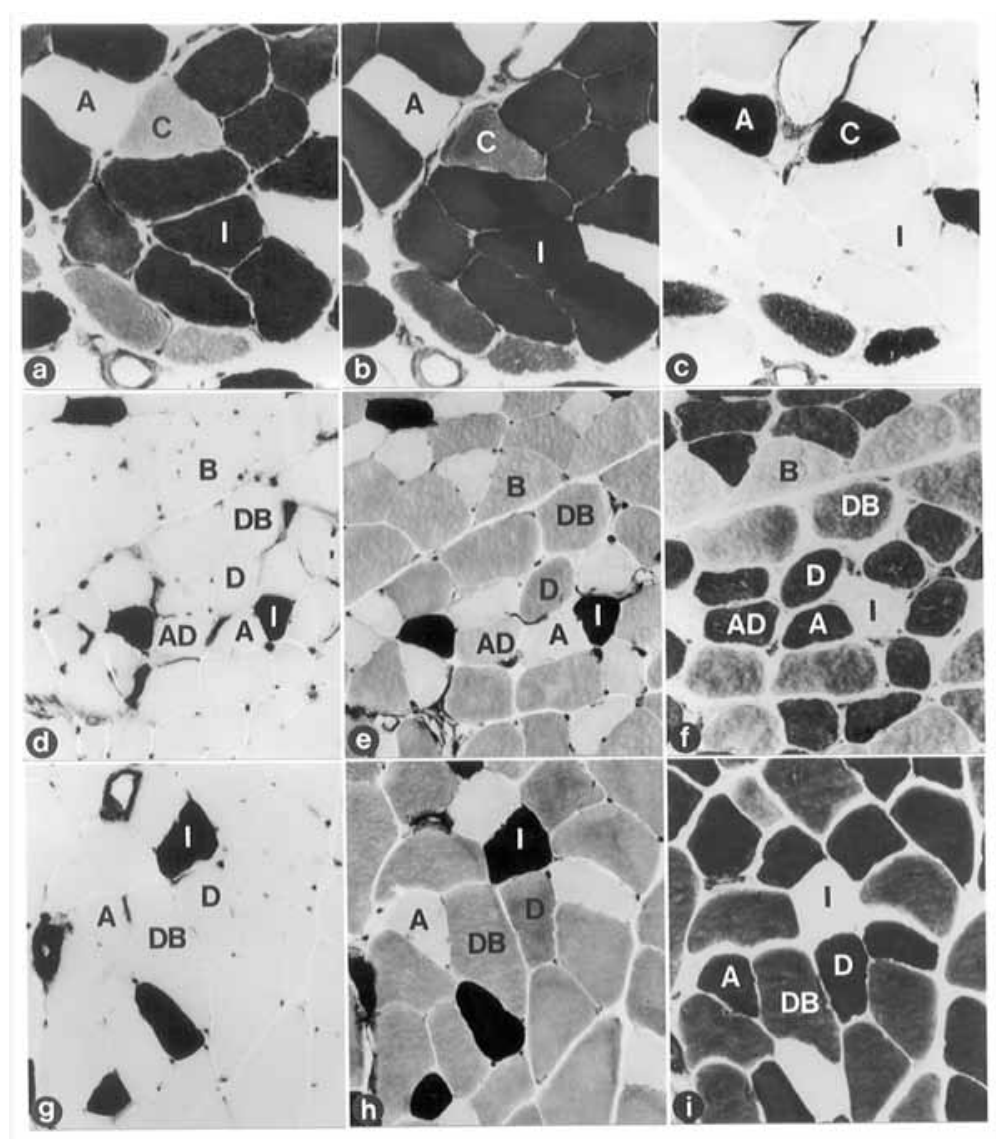

Figure 1. Histochemical reaction to mATPase in transversal sections of the soleus ( $a, b, c)$, the extensor digitorum longus (d, e, f) and the plantaris $(\mathrm{g}, \mathrm{h}, \mathrm{i})$ of Wistar rats in $\mathrm{pH} 4.3(\mathrm{a}, \mathrm{d}, \mathrm{g}), 4.6(\mathrm{~b}, \mathrm{e}, \mathrm{h})$ and 10.4 (c, f, i). I-fibers of type I, C-IIC, A-IIA, AD-IIAD, D-IID, DB-IIDB and B-IIB. Inc. 900x.

Table 1. Relative weight (g) of SOL, EDL and PL muscles of animals from groups GS and GT.

\begin{tabular}{cccc}
\hline Groups & \multicolumn{3}{c}{ Muscles } \\
\cline { 2 - 4 } Treatments & SOL & EDL & PL \\
\hline SG I & $0,105 \pm 0,010^{\mathrm{aA}}$ & $0,135 \pm 0,003^{\mathrm{bA}}$ & $0,300 \pm 0,012^{\mathrm{bA}}$ \\
TG I & $0,110 \pm 0,010^{\mathrm{bA}}$ & $0,128 \pm 0,002^{\mathrm{aB}}$ & $0,284 \pm 0,043^{\mathrm{aA}}$ \\
SG II & $0,140 \pm 0,010^{\mathrm{dA}}$ & $0,153 \pm 0,023^{\mathrm{deA}}$ & $0,350 \pm 0,014^{\mathrm{deA}}$ \\
TG II & $0,127^{\mathrm{aA}} \pm 0,004^{\mathrm{cB}}$ & $0,136 \pm 0,031^{\mathrm{bcB}}$ & $0,319 \pm 0,014^{\mathrm{cB}}$ \\
SG III & $0,141^{\mathrm{deA}} 0,021^{\mathrm{deA}}$ & $0,151 \pm 0,000^{\mathrm{dA}}$ & $0,348 \pm 0,010^{\mathrm{dA}}$ \\
TG III & $0,154 \pm 0,023^{\mathrm{fA}}$ & $0,162 \pm 0,023^{\mathrm{fB}}$ & $0,385 \pm 0,011^{\mathrm{fB}}$ \\
\hline
\end{tabular}

Average values \pm SD. Different letters (lower case between the groups and upper case in the group) in a row indicate significant difference $(\mathrm{P}<0.05)$.

Table 2. Distribution of fibers (I, IC, IIC and IIA) in the SOL muscle of the animals from SG and TG groups.

\begin{tabular}{ccccc}
\hline Groups / & \multicolumn{4}{c}{ Types of fibers (\%) } \\
\cline { 2 - 5 } Treatments & I & IC & IIC & IIA \\
\hline GSI & $92.56^{\mathrm{aA}}$ & $0.27^{\mathrm{aA}}$ & $1.78^{\mathrm{bcA}}$ & $5.43^{\mathrm{eB}}$ \\
GTI & $93.62^{\mathrm{bB}}$ & $0.45^{\mathrm{aA}}$ & $2.73^{\mathrm{dB}}$ & $3.18^{\mathrm{dA}}$ \\
GSII & $94.36^{\mathrm{bA}}$ & $0.00^{\mathrm{aA}}$ & $2.53^{\mathrm{cB}}$ & $3.09^{\mathrm{dB}}$ \\
GTII & $99.72^{\mathrm{dB}}$ & $0.00^{\mathrm{aA}}$ & $0.27^{\mathrm{aA}}$ & $0.00^{\mathrm{aA}}$ \\
GSIII & $93.61^{\mathrm{bA}}$ & $0.49^{\mathrm{aA}}$ & $3.31^{\mathrm{dB}}$ & $2.57^{\mathrm{cB}}$ \\
GTIII & $97.63^{\mathrm{cB}}$ & $0.00^{\mathrm{aA}}$ & $0.99^{\mathrm{abA}}$ & $1.36^{\mathrm{bA}}$ \\
\hline
\end{tabular}

Different letters (lower case between the groups and upper case in the group) in a row indicate significant difference $(\mathrm{P}<0.05)$. decrease $(\mathrm{p}<0.05)(97.63 \%)$. Type IIA fibers showed a significant increase $(\mathrm{p}<0.05)$ after 3 weeks $(3.18 \%)$, a significant decrease $(\mathrm{p}<0.05)$ after 6 weeks of training $(0.00 \%)$ and after 9 weeks a significant increase $(\mathrm{p}<0.05)(1.36 \%)$. The distribution of IC and IIC fibers was not significant $(\mathrm{p}>0.05)$ among the trained groups in the course of the 9 weeks (Table 2 ).

To the EDL muscle the TGI showed significant increase $(\mathrm{p}<0.05)$ of IID, IIA and I fibers $(31.28 \%, 25.72 \%$ and $8.76 \%)$ with a significant decrease of IIB and IIDB fibers $(24.56 \%$ and $8.92 \%$ ) when compared to SGI. In the TGII, IIAD fibers showed decrease (1.22\%), not a significant value, although, $(\mathrm{p}>0.05)$ when compared to SGII, while IA, IIA, IID and IIDB fibers $(3.71 \%, 19.53 \%, 22.80 \%$ and $4.72 \%)$ had a significant decrease 
$(\mathrm{p}<0.05)$. TGIII showed significant decrease $(\mathrm{p}<0.05)$ of IIA, IIAD and IIDB fibers $(30.39 \%, 3.37 \%$ and $7.09 \%)$ when compared to SGIII. As for type I fibers $(6.72 \%)$, there was a decrease, although not significant $(\mathrm{p}>0.05)$ in the group (Table 3 ). The distribution of fiber types of the EDL muscles among the trained groups TGI, TGII and TGIII showed significant difference $(\mathrm{p}<0.05)$ after 3,6 and 9 weeks of training fibers I, IIA and IIB. Fibers of the type IIAD didn't show significant differences $(\mathrm{p}>0.05)$ among the trained groups in the course of the 9 weeks (Table 3 ).

The distribution of IIC fibers in the PL muscle analyzed didn't show significant difference ( $p>0.05)$ among TGI and SGI, although a significant increase $(\mathrm{p}<0.05)$ of fibers I and IIB ( $13.74 \%$ and $33.36 \%$ ) was observed, as well as a significant decrease $(\mathrm{p}<0.05)$ of IIA, IIAD, IID and IIDB fibers $(16.66 \%, 3.45 \%, 28.62 \%$ and $3.70 \%)$. In the TGII group there was a significant increase $(\mathrm{p}<0.05)$ of IID and IIAD fibers $(26.88 \%$ and $4.17 \%)$, a not significant decrease $(p>0.05)$ of I, IIA and IIB fibers $(6.56 \%, 16.87 \%$ and $42.04 \%)$ and not significant increase $(\mathrm{p}>0.05)$ of IIDB fibers in relation to the SGII group. TGIII showed significant increase $(\mathrm{p}<0.05)$ of IIAD and IIB fibers $(8.15 \%$ and $30.67 \%)$ with significant decrease $(\mathrm{p}<0.05)$ of I, IIA and IID fibers $(10.14 \%, 22.08 \%$ and $24.81 \%)$. IIDB fibers didn't show a significant difference $(\mathrm{p}>0.05)$ when compared to the SGIII (Table 4). The distribution of fiber types in the PL muscle among the trained groups (TGI, TGII and TGIII) showed significant difference $(\mathrm{p}<0.05)$ after 3,6 and 9 weeks of training fibers type I, IIB and IID. Fibers IIC, IIA, IIAD and IIDB didn't show significant differences $(p>0.05)$ among the trained groups in the course 9 weeks (table 4 ).

\section{Discussion}

The functional unit of the motor system, the motor unit, is composed of a motor neuron and a bunch of muscle fibers with similar, if not identical, structural and functional properties. To form a muscle, many (from tens to hundreds) motor units are assembled together, and each brings its own specific and distinct contribution. The selective recruitment of motor units enables a muscle to respond in the best manner to the functional demands (SCHIAFFINO and REGGIANI, 2011). The heterogeneity of the muscle fibers is the base of the flexibility which allows the same muscle to be used for various tasks from continuous low-intensity activity (e.g., posture), to repeated submaximal contractions (for example, locomotion), and to fast and strong maximal contractions (jumping, kicking). In addition, the structural and functional properties of the fibers, which are generally referred to as fiber phenotype, can change in response to hormonal and neural influences, nerve-activity being a major determinant of the fiber type profile. This property is defined muscle plasticity or malleability. The molecular mechanisms of the heterogeneity and plasticity of muscle fibers have been the object of intensive investigation, and several signaling pathways which have been identified appear to mediate the emergence of specific muscle phenotypes as stated by Schiaffino and Reggiani (2011).

The adaptation of the stimulated organism by the tension overload is the synthesis of myofibrillar contractile protein, the most important mechanism to cause skeletal muscle hypertrophy. From a functional viewpoint, the quality of parallel stimulated fitness is force, that is, the contractile capacity of muscles (CARTER, RENNIE, HAMILTON et al., 2001; MCAINCH, LEE, BRUCE et al., 2003). The detailed protein makeup and metabolic profile of different muscle fiber types are largely unexplored but would clearly be invaluable in understanding the effects of fiber function at the molecular level (MURGIA, NAGARAJ, DESHMUKH et al., 2015).

Metabolic overload from exercises also contributes to muscular fiber hypertrophy, mainly due to the stimulus to increase the volume, the number of mitochondria and the

Table 3. Distribution of fibers (I, IIA, IIAD, IID, IIDB and IIB) (\%) in the EDL muscle of the animals from SG and TG groups.

\begin{tabular}{ccccccc}
\hline Groups $/$ & \multicolumn{5}{c}{ Types of fibers (\%) } \\
\cline { 2 - 7 } Treatments & I & IIA & IIAD & IID & IIDB & IIB \\
\hline GSI & $4.05^{\mathrm{aA}}$ & $17.85^{\mathrm{aA}}$ & $2.93^{\mathrm{bcB}}$ & $26.56^{\mathrm{cA}}$ & $10.17^{\mathrm{eB}}$ & $38.42^{\mathrm{dB}}$ \\
GTI & $8.76^{\mathrm{cB}}$ & $25.72^{\mathrm{eB}}$ & $0.63^{\mathrm{aA}}$ & $31.38^{\mathrm{eB}}$ & $8.92^{\mathrm{dA}}$ & $24.56^{\mathrm{aA}}$ \\
GSII & $7.54^{\mathrm{bB}}$ & $23.53^{\mathrm{dB}}$ & $1.25^{\mathrm{aA}}$ & $29.75^{\mathrm{dB}}$ & $5.81^{\mathrm{bB}}$ & $32.09^{\mathrm{cA}}$ \\
GTII & $3.71^{\mathrm{aA}}$ & $19.53^{\mathrm{bA}}$ & $1.22^{\mathrm{aA}}$ & $22.80^{\mathrm{aA}}$ & $4.72^{\mathrm{aA}}$ & $48.00^{\mathrm{eB}}$ \\
GSIII & $6.72^{\mathrm{bA}}$ & $21.61^{\mathrm{cA}}$ & $2.41^{\mathrm{bA}}$ & $32.36^{\mathrm{fB}}$ & $5.21^{\mathrm{abA}}$ & $31.65^{\mathrm{cB}}$ \\
GTIII & $7.18^{\mathrm{bA}}$ & $30.39^{\mathrm{fB}}$ & $3.37^{\mathrm{cB}}$ & $25.58^{\mathrm{bA}}$ & $7.09^{\mathrm{cB}}$ & $26.37^{\mathrm{bA}}$ \\
\hline
\end{tabular}

Different letters (lower case between the groups and upper case in the group) in a row indicate significant difference $(\mathrm{P}<0.05)$.

Table 4. Distribution of fibers (I. IIA. IIAD. IID. IIDB and IIB) (\%) in the EDL muscle of the animals from SG and TG groups.

\begin{tabular}{cccccccc}
\hline Groups & \multicolumn{9}{c}{ Types of fibers (\%) } \\
\cline { 2 - 8 } Treatments & I & IIC & IIA & IIAD & IID & IIDB & IIB \\
\hline GSI & $11.77^{\mathrm{cA}}$ & $0.13^{\mathrm{aA}}$ & $19.66^{\mathrm{bB}}$ & $4.70^{\mathrm{cB}}$ & $33.88^{\mathrm{fB}}$ & $5.40^{\mathrm{cB}}$ & $24.42^{\mathrm{bA}}$ \\
GTI & $13.74^{\mathrm{dB}}$ & $0.43^{\mathrm{aA}}$ & $16.66^{\mathrm{aA}}$ & $3.45^{\mathrm{bA}}$ & $28.62^{\mathrm{dA}}$ & $3.70^{\mathrm{bA}}$ & $33.36^{\mathrm{dB}}$ \\
GSII & $7.67^{\mathrm{bB}}$ & $0.79^{\mathrm{aA}}$ & $19.21^{\mathrm{bB}}$ & $1.41^{\mathrm{aA}}$ & $22.52^{\mathrm{aA}}$ & $2.39^{\mathrm{aA}}$ & $45.97^{\mathrm{fB}}$ \\
GTII & $6.56^{\mathrm{aA}}$ & $0.39^{\mathrm{aA}}$ & $16.87^{\mathrm{aA}}$ & $4.17^{\mathrm{bcB}}$ & $26.88^{\mathrm{cB}}$ & $3.05^{\mathrm{bA}}$ & $42.04^{\mathrm{eA}}$ \\
GSIII & $18.75^{\mathrm{eB}}$ & $0.76^{\mathrm{aA}}$ & $24.39^{\mathrm{dB}}$ & $6.61^{\mathrm{dA}}$ & $31.26^{\mathrm{eB}}$ & $3.84^{\mathrm{bA}}$ & $14.65^{\mathrm{aA}}$ \\
GTIII & $10.14^{\mathrm{bA}}$ & $0.31^{\mathrm{aA}}$ & $22.08^{\mathrm{cA}}$ & $8.15^{\mathrm{eB}}$ & $24.81^{\mathrm{bA}}$ & $3.81^{\mathrm{bA}}$ & $30.67^{\mathrm{cB}}$ \\
\hline
\end{tabular}

Different letters (lower case between the groups and upper case in the group) in a row indicate significant difference $(\mathrm{P}<0.05)$. 
accumulation of glycogen and water. A greater stimulus to vascularization, typical of the metabolic overload, although extracellular, also contributes to the volume of muscles (TARPENNING, HAMILTON-WESSLER, WISWELL et al., 2004). At the same time there is the increase in aerobic or anaerobic resistance, depending on the type of effort involved in training. The amount of glycogen may triple in adequately trained muscles, and considering that due to molecular hydration, each gram of glycogen carries almost three grams of water, one can understand the huge increase of intracellular water resulting from the process. For several reasons, anaerobic metabolic overload associates with a higher degree of muscular hypertrophy than aerobic (TARPENNING, HAMILTON-WESSLER, WISWELL et al., 2004). Mitochondria and vascularization increase in the anaerobic metabolic overload according to the parallel activation of aerobic metabolism. The consistence of the muscle increases in proportion to the degree of metabolic overload according to the saturation of glycogen and water. Fiber type diversification may also reflect an adaptation to the whole body metabolism. Two aspects of this relation can be considered. First, the skeletal muscle is the main protein reservoir in the body, and aminoacid release from muscle during prolonged starvation is essential to maintain plasma glucose concentration via gluconeogenesis in the liver and for new protein synthesis (SCHIAFFINO and REGGIANI, 2011).

An aspect that may be misinterpreted when comparing the effects of force and aerobic exercises is the distribution of body composition. In this paper the increase of muscle mass (MM) may have compensated in weight the decrease of fat mass (FM). The fat mass consists of all the lipids and the lean body mass encompasses water, proteins and mineral components (VÍVOLO and FIORETTI, 1999). The results demonstrate a decrease in the relative weight of the SOL, EDL and PL muscles in TGI and TGII groups. In TGIII the relative weight of the SOL, EDL and PL muscles increased, because in all the types of exercise there was tension and metabolic overload in the skeletal muscle. As for the long-term exercises, such as running, the higher the speed of movements, the higher the tension overload, and the higher the degree of anaerobiosis of the effort. This is why sprinters in general show increase of mass muscle (MCAINCH, LEE, BRUCE et al., 2003; TARPENNING, HAMILTON-WESSLER, WISWELL et al., 2004).

The adult skeletal muscle is capable of adapting its properties in response to changing functional demands (SALMONS, 2017). The diversity of fibers provides the muscle an adaptation capacity in its myofibrillar system to continuously adjust to functional needs. The muscle capacity to adapt to determinate stimulus is called muscle plasticity (PETTE and STARON, 2000, 2001; BALDWIN and HADDAD, 2001).

Considering long-term physical exercises, this study observed significant change in the distribution of muscular fiber types when comparing the TG and SG groups, with a tendency of increase of type I fibers and of decrease of types IIC and IIA fibers in the SOL muscle. The EDL muscle showed a tendency of increase of IIA fibers and a decrease of IIB and ID. The PL muscle showed a tendency of increase of IIA and IIAD fibers and a decrease of the IID type. These results show that physical exercise causes changes in the distribution of the fiber types in the skeletal muscles of rats and that muscle fibers have the capacity to adapt to a determinate stimulus without modifying their composition or altering the characteristic of each muscle (HAWLEY, 2002; MCAINCH, LEE, BRUCE et al., 2003;
TARPENNING, HAMILTON-WESSLER, WISWELL et al., 2004). In the SOL muscle, fibers of type I predominate, and in the EDL and PL muscles the predominance is of type II fibers (WAHRMANN, WINAND and RIEU, 2001; WIDRICK, STELZER, SHOEPE et al., 2002). After the training period with long-term exercises a significant change $(\mathrm{p}<0.05)$ was observed in the distribution of fiber types of the SOL, EDL and PL muscles among the TGI, TGII and TGIII groups, changes which would identify the adaptations of these muscles to the physical exercise applied in the course of 9 weeks. The effects of long-term physical exercises caused a change of the relative weight of the SOL, EDL and PL muscles and significant changes in the distribution of fibers in the skeletal muscles of rats.

\section{Conclusion}

Physical exercise causes changes in the distribution of fiber types in the skeletal muscles of rats and confirms the ability of the fibers to adapt to the requirements of the proposed physical exercise in order to achieve a better performance. This emphasizes that muscular plasticity allows a wide and indispensable usability among various physical performances.

\section{References}

BALDWIN, KM. and HADDAD, F. Plasticity in skeletal, cardiac, and smooth muscle invited review: effects of different activity and inactivity paradigms on myosin heavy chain gene expression in striated muscle. Journal of Applied Physiology, 2001, no. 90, p. 345-357.

BROOKE, MH. and KAISER, KK. Three "myosin adenosine tryphosphatase" systems: the nature of their $\mathrm{pH}$ hability and sulfhydryl dependence. Journal of Histochemistry \& Cytochemistry, 1970, n. 18 , p. 670-672.

CARTER, SL., RENNIE, CD., HAMILTON, SJ. and TARNOPOLSKY. Changes in skeletal muscle in males and females following endurance training. Canadian Journal of Physiology and Pharmacology, 2001, vol. 79 , n. 5 , p. 386-392.

DEMIREL, HA., POWERS, SK., NAITO, H., HUGHES, M. and COOMBES, JS. Exercise-induced alterations in skeletal muscle myosin heavy chain phenotype: dose-response relationship. Journal of Applied Physiology, 1999, vol. 86, n. 3, p. 1002-1008. PMid:10066716.

GUTH, L. and SAMAHA, FJ. Procedure for the histochemical. demonstration of actomyosin ATPase. Experimental Neurology, 1970, vol. 28 , n. 2, p. 365-367. PMid:4248172. http://dx.doi. org/10.1016/0014-4886(70)90244-X.

HAWLEY, JA. Adaptations of skeletal muscle to prolonged, intense endurance training. Clinical and Experimental Pharmacology \& Physiology, 2002, vol. 29, n. 3, p. 218-222. PMid:11906487. http:// dx.doi.org/10.1046/j.1440-1681.2002.03623.x.

KADI, F., ERIKSSON, A., HOLMNER, S., BUTLER-BROWNE, GS. and THORNELL, LE. Cellular adaptation of the trapezius muscle in strength-trained athletes. Histochemistry and Cell Biology, 1999, n. 111, p. 189-195.

MCAINCH, AJ., LEE, JS., BRUCE, CR., TUNSTALL, RJ., HAWLEY, JA. and CAMERON-SMITH, D. Dietary regulation of fat oxidative gene expression in different skeletal muscle fiber types. Obesity Research, 2003, vol. 11, n. 11, p. 1471-147. PMid:14694211. http://dx.doi.org/10.1038/oby.2003.197.

MURGIA, M., NAGARAJ, N., DESHMUKH, AS., ZEILER, M., PASQUA CANCELLARA, P., MORETTI, I., REGGIANI, C., SCHIAFFINO, S. and MANN, M. Single muscle fiber proteomics reveals unexpected mitochondrial specialization. EMBO Reports, 
2015, vol. 16, n. 3, p. 387-395. PMid:25643707. http://dx.doi. org/10.15252/embr.201439757.

PETTE, D. and STARON, RS. The continuum of pure and hybrid myosin heavy chain based types in rat skeletal muscle. Histochemistry, 1993, vol. 100, n. 2, p. 149-153. PMid:8244766. http://dx.doi. org/10.1007/BF00572901.

PETTE, D. and STARON, RS. Myosin isoforms, muscle fiber types, and transitions. Microscopy Research and Technique, 2000, vol. 50, n. 6 , p. 500-509.

PETTE, D. and STARON, RS. Transitions of muscle fiber phenotypic profiles. Histochemistry and Cell Biology, 2001, vol. 115, n. 5, p. 359-372.

POWERS, SK., CRISWELL, D., LAWLER, J., MARTIN, D., JI, LL., HERB, RA. and DUDLEY, G. Influence of exercise and fiber type on antioxidant enzyme activity in rat skeletal muscle. The American Journal of Physiology, 1994, vol. 266, n. 2 Pt 2, p. R375-R380. PMid:8141392.

SALMONS, S. The adaptive response of skeletal muscle: what is the evidence? Muscle \& Nerve, 2017, In press. PMid:28857207. http:// dx.doi.org/10.1002/mus.25949.

SCHIAFFINO, S. and REGGIANI, C. Fiber types in mammalian skeletal muscles. Physiological Reviews, 2011, vol. 91, n. 4, p. 1447-1531. PMid:22013216. http://dx.doi.org/10.1152/physrev.00031.2010.

SULlivaN, V., POWERS, S., CRISWELL, D., TUMER, N., LAROCHELLE, J. and LOWENTHAL, D. Myosin heavy chain composition in young and old rat skeletal muscle: effects of endurance exercise. Journal of Applied Physiology, 1995, vol. 78, n. 6, p. 21152120. PMid:7665407.

TARPENNING, KM., HAMILTON-WESSLER, M., WISWELL, RA. and HAWKINS, SA. Endurance training delays age of decline in leg strength and muscle morphology. Medicine and Science in Sports and Exercise, 2004, vol. 36, n. 1, p. 74-78. PMid:14707771. http:// dx.doi.org/10.1249/01.MSS.0000106179.73735.A6.

VÍVOLO, MA. and FIORETTI, AMB. Metabolismo hormonal e de glícides nas atividades física e esportiva. In: GHORAYEB, N. and BARROS NETO, TL. O exercício: preparação fisiológica, avaliação médica, aspectos especiais e preventivos. São Paulo: Atheneu, 1999.

WAHRMANN, JP., WINAND, R. and RIEU, M. Plasticity of skeletal myosin in endurance-trained rats (I). A quantitative study. European Journal of Applied Physiology, 2001, n. 84, p. 367-372.

WIDRICK, JJ., STELZER, JE., SHOEPE, TC. and GARNER, DP. Functional properties of human muscle fibers after short-term resistance exercise training. American Journal of Physiology. Regulatory, Integrative and Comparative Physiology, 2002, vol. 283, n. 2, p. 408-416. PMid:12121854. http://dx.doi.org/10.1152/ajpregu.00120.2002.

Received December 9, 2016 Accepted October 2, 2017 